\title{
Concomitant Medication Class Code
}

National Cancer Institute

\section{Source}

National Cancer Institute. Concomitant Medication Class Code. NCI Thesaurus. Code C83220.

A character or string that represents a concomitant medication class. 